\title{
FILANTROPI ISLAM RUMAH SABILILLAH DAN PENANAMAN KARAKTER KEPEDULIAN SOSIAL PADA SISWA DI SDIT AN NAJAH JATINOM KLATEN
}

\author{
Zaid Munawar \\ Pascasarjana UIN Sunan Kalijaga Yogyakarta \\ Jl. Laksda Adisucipto, Caturtunggal, Kec. Depok, Kabupaten Sleman, Yogyakarta 55281 \\ e-mail:munawarzaid@yahoo.com
}

\begin{abstract}
The purposes of this research were (1) to describe the implementation of social ewareness character to students in SDIT An Najah Jatinom Klaten, (2) to describe the change in character building of social ewareness from students in SDIT An Najah Jatinom Klaten. This research was a qualitative research. Methods of data collection were conducted in four ways, namely (1) Observation, (2) Interview, (3) Documentation, (4) Questionnaire containing student social attitude at SDIT An Najah. The results of this research are: (1) the implementation of social character building of students in SDIT An Najah is done through socialization strategy, fundraising strategy and distribution strategy in Islamic philanthropy of Rumah Sabilillah, and (2) Islamic Filantrophy approach of Rumah Sabilillah able to improve character social awareness of students in SDIT A Najah, as evidenced by several things namely; the increasing of philanthropy fund of Rumah Sabilillah, the increasing of the mustahiq that can be supported, and the widespread use of philanthropy fund which is not only limited to the five excellent programs of Rumah Sabilillah, but also able to provide assistance to the construction of mosque in Jatinom subdistrict and surrounding area.
\end{abstract}

Keywords: Philanthropy Rumah Sabilillah, Character of Student Concern.

\begin{abstract}
Abstrak
Tujuan dari penelitian ini, yaitu (1) terdeskripsinya implementasi penanaman karakter kepedulian sosial pada siswa di SDIT An Najah Jatinom Klaten, (2) terdeskripsinya perubahan peningkatan karakter kepedulian sosial pada siswa di SDIT An Najah Jatinom Klaten. Penelitian ini merupakan jenis penelitian kualitatif. Metode pengumpulan data dilakukan dengan empat cara, yaitu (1) Observasi, (2) Wawancara, (3) Dokumentasi, (4) Angket yang memuat sikap peduli sosial siswa di SDIT An Najah. Adapun hasil dalam penelitian ini, yaitu (1) implementasi penanaman karakter kepedulian sosial siswa di SDIT An Najah dilakukan melalui strategi sosialisasi, strategi fundraising, dan strategi pendistribusian dalam kegiatan filantropi Islam Rumah Sabilillah, dan (2) pendekatan Filantropi Islam Rumah Sabilillah mampu meningkatkan karakter kepedulian sosial siswa di SDIT A Najah, yang dibuktikan dengan beberapa hal yaitu; meningkatnya dana filantropi Rumah Sabilillah, bertambahnya para mustahiq yang mampu disantuni, dan melebarnya penggunaan dana filantropi yang tidak hanya terbatas pada lima program unggulan Rumah Sabilillah, tetapi juga mampu memberikan bantuan kepada pembangunan masjid di wilayah kecamatan Jatinom dan sekitarnya.
\end{abstract}

Kata Kunci: Filantropi Rumah Sabilillah, Karakter Kepedulian Siswa 


\section{Pendahuluan}

Secara konseptual, filantropi merupakan suatu bentuk sikap kepedulian seseorang atau sekelompok orang terhadap orang lain yang duwujudkan dengan memberi atas dasar rasa cinta kepada sesama. Kegiatan filantropi ini dilakukan sebab baik di dalam al-Quran maupun hadits banyak dijumpai ayat dan riwayat yang menganjurkan kedermawanan dalam berbagai bentuknya mulai dari zakat, infak, atau pun sedekah. ${ }^{1}$ Lebih luasnya, ekspresi filantropi tidak hanya dalam konteks memberi saja melainkan bagaimana cara mendapatkandana (fundraising),${ }^{2}$ manajemen (management), hingga sampai pada tahap memberikannya/mentasyarufkannya (distribution) kepada yang membutuhkan. Inilah wujud filantropi Islam yang bisa dilihat pada sebuah komunitas di dalam masyarakat, terutama di lembaga-lembaga filantropi yang berdiri di berbagai wilayah di Indonesia.

Praktek filantropi di atas merupakan wujud dari penerjemahan ajaran-ajaran yang ada di dalam al-Qur-an maupun hadits. Dana filantropi berupa zakat, infaq, maupun sedekah dapat digunakan untuk kepentingan masyarakat luas, seperti masalah pengentasan kemiskinan, pemerataan kesejahteraan, kebencanaan, pembangunan tempat ibadah, maupun peningkatan pendidikan. Itulah wujud praktek filantropi Islam dalam kehidupan bermasyarakat. Betapa pentingnya apabila filantropi Islam dapat tumbuh subur dan memberikan kontribusi yang nyata dalam kehidupan bermasyarakat.

${ }^{1}$ Di antara ayat-ayat di dalam Al-Quran yang menekankan tentang filantropi yaitu QS. al-Taubah (9): 34, 71; Q.S. al-Baqarah (2): 2, 3, 272; Q.S. ali-Imran (3): 180.

${ }^{2}$ Fundrising ialah aktivitas penggalangan daya/ dana oleh sebuah lembaga. Richard Holloway, Menuju Kemandirian Keuangan (Jakarta: Yayasan Obor, 2002), hlm. 21-22.
Berkaca dari urgensi di atas, menjadi suatu hal yang menarik apabila filantropi dikaitkan dengan pendidikan, terutama pendidikanIslam.Dalamurgensipendidikan, selain sebagai transfer of knowledge (transfer ilmu), pendidikan juga berfungsi sebagai transfer of value (transfer nilai). Artinya, pendidikan Islam di sini berfungsi sebagai agen untuk perubahan sosial yang diselenggarakan oleh lembaga-lembaga pendidikan. Dalam hal ini, lebih spesifik lagi bahwa pendidikan formal berfungsi sebagai proses pembaharuan sosial. ${ }^{3}$ Oleh karena itu, terdapat ruang yang sangat lebar untuk menghubungakan antara filantropi dan pendidikan Islam. Nilai-nilai filantropi seperti kebiasaan berderma karena rasa cinta kasih kepada sesama dapat ditransferkan melalui pembelajaran di dalam pendidikan Islam, terutama di lembaga formal. Tujuan dari pada itu tidak lain adalah untuk menumbuhkan jiwa-jiwa filantropisme, yaitu kebiasaan memberi kepada sesama yang ditanamkan melalui jalur pendidikan. Hal ini didasarkan pula bahwa di dalam Islam manusia dianjurkan harus saling berkasih sayang, tolong-menolong, sebagai wujud penerapan sebagai manusia yang sebenarnya dalam hidup bermasyarakat. Dengan demikian, terdapat keselarasan antara filantropi Islam dengan pendidikan Islam yang sama-sama mendasarkan pada ajaran di dalam Al-Qur'an maupun hadits.

Kata kunci dari uraian di atas ialah mengarah pada urgensi filantropi dan pendidikan. Keduanya memiliki arti penting jika dikaitkan dengan pendidikan karakter siswa, yaitu pendidikan untuk menanamkan kepadaanaktentangkepeduliansosial.Dalam hal ini, pendidikan sangat penting dalam mengubah karakter seseorang. Demikian juga, karakter merupakan hal yang sangat penting dan mendasar dalam kehidupan. Orang-orang yang berkarakter baik dan

3 Abu Ahmadi, Sosiologi Pendidikan (Jakarta: PT Renika Cipta, 2007), 25. 
kuat secara individual maupun sosial ialah mereka yang memiliki akhlak, moral, dan budi pekerti yang baik. Mengingat itu semua sangat penting, maka harus diawali dari dunia pendidikan, mulai dari sekolah dasar (SD), atau bahkan dari usia dini (TK/PAUD) untuk memberikan pendidikan karakter kepada peserta didik.

Dalam konteks sekarang, pendidikan karakter sangat relevan untuk mengatasi krisis moral yang sedang melanda generasi bangsa dan bahkan memasuki dunia pendidika. ${ }^{4}$ Krisis tersebut antara lain berupa meningkatnya pergaulan bebas, maraknya angka kekerasan anak, meningkatnya kasus kejahatan terhadap sesama teman, termasuk juga rendahnya tingkat kepedulian sosial pada diri anak. Dalam kasus krisis sosial yang terakhir, yaitu rendahnya kepedulian sosial akan berakibat pada rendahnya tingkat solidaritas antar sesama dalam hidup bermasyarakat. Oleh sebab itu, maka rendahnya kepedulian sosial dan pentingnya sikap kepedulian menjadi sesuatu yang harus disikapi oleh lembaga pendidikan. Betapa pentingnya apabila sikap kepedulian yang diwujudkan dengan kebiasaan berderma tumbuh subur di lingkungan sekolah dan dapat memberikan kontribusi yang nyata dalam mewujudkan kebaikan bersama seperti pengentasan kemiskinan, peningkatan kesejahteraan, dan bahkan peningkatan dalam dunia pendidikan.

Untuk mewujudkan harapan di atas, maka perlu usaha-usaha strategis dan inovatif dalam menumbuhkan jiwajiwa kedermawanan pada diri anak sejak usia dini. Harapannya ialah agar mereka memiliki kepekaan sosial sehingga tumbuh menjadi pribadi yang memiliki jiwa sosial tinggi terhadap sesama atas dasar cinta dan kasih yang murni. Dengan demikian,

4 Akla, "Desain Pembelajaran Bahasa Arab berbasis Penanaman Karakter untuk Anak Usia Dini," Elementary: Jurnal Ilmiah Pendidikan Dasar 3, no. 2 (2017): 138. di sinilah pentingnya aktivisme filantropi di dalam dunia pendidikan sebagai usaha strategis untuk mewujudkan pendidikan karakter siswa. Dengan pendidikan ini, maka jiwa kedermawanan akan mewujud pada sikap peduli anak kepada sesama sehingga berperan penting untuk ikut berpartisipasi dalam mewujudkan kesejahteraan di masyarakat.

Dengan dasar di atas, maka lembaga pendidikan memiliki tanggungjawab untuk menanamkan nilai-nilai atau mentalitas filantropi. Sudah saatnya lembaga pendidikan menjadikan filantropi sebagai salah satu subyek yang dipelajari di sekolah. Di sini peran tenaga pendidik (guru) menjadi salah satu bagian dari stakeholder pendidikan filantropi.

Suatu lembaga pendidikan tingkat dasar yang memiliki perhatian besar terhadap filantropi Islam adalah Sekolah Dasar Islam Terpadu (SDIT) An Najah yang terletak di kecamatan Jatinom, kabupaten Klaten, provinsi Jawa Tengah. Sekolah ini memiliki sebuah "Laboratorium Sosial" yang dijadikan sebagai wadah bagi semua warga sekolah dari mulai siswa-siswi, guru, maupun karyawan dalam segala bentuk kegiatan yang berbau sosial. Laboratorium Sosial ini diberi nama Rumah Sabilillah.

Melalui lembaga Rumah Sabilillah, SDIT An Najah menggunakannya sebagai pendekatan untuk menumbuhkan karakter sikap kepedulian sosial kepada seluruh peserta didik. Oleh karena itu, penelitian ini dilakukan untuk mengetahui bagaimana implementasi penanaman karakter kepedulian sosial pada siswa di SDIT An Najah melalui lembaga filantropi Rumah Sabilillah dan seberapa besar peningkatan karakter kepedulian sosial siswa di SDIT An Najah dengan pendekatan filantropi Rumah Sablillah. 


\section{Kerangka Teori}

\section{Pengertian Filantropi}

Filantropi berasal dari bahasa Yunani, yaitu philanthropy, philan artinya cinta dan antrhopos artinya manusia. Secara harfiah, filantropi merupakan konseptualisasi dari praktek memberi (giving), pelayanan (services), dan association (asosiasi) secara suka rela untuk membantu pihak lain yang membutuhkan sebagai ekspresi rasa cinta. ${ }^{5}$ Secara konseptual, para ahli memberikan definisi filantropi yang sangat beragam. Menurut Payton dan Moody filantroi didefinisikan sebagai sebuah tindakan sukarela untuk kepentingan kemaslahan publik. Adapun definisi secara luas diungkapkan oleh W.K. Kolleg Foundation bahwa konsepi filantropi yaitu memberikan waktu, uang, dan pengetahuan bagaimana cara mengembangkan kebaikan bersama (public good). Artinya bahwa keterlibatan secara luas seluruh aktivitas manusia dalam berbagai bidang dengan penuh kerelaan, partisipasi, dedikasi, gagasan, waktu luang, kontribusi materi merupakan bagian yang tidak dapat dipisahkan dari konsep filantropi. ${ }^{6}$ Hilman Latief pun memaknai bahwa istilah "memberi" tidak sematamata hanya dimaknai aspek materialnya, tapi juga aspek lain yang lebih luas, yaitu meluangkan waktu dan menyumbangkan pengetahuan untuk kepentingan sosial yang lebih luas. Istilah "memberi" atau "berbagi" juga dapat diartikulasikan dalam bentuk kesadaran, dukungan, komitmen, dedikasi, partisipasi, dan keterlibatan masyarakat dakam mengangkat persoalan kemiskinan serta memberikan solusi terhadap problem

${ }^{5}$ Chaider S. Bamualim dan Irfan Abu Bakar, Revitalisasi Filantropi Islam (Jakarta: PBB UIN Syarif Hidayatullah, 2005), 3.

${ }^{6}$ Abidin Zaenal, "Manifestasi dan Latensi Lembaga Filantropi Islam dalam Praktek Pemberdayaan Masyarakat: Suatu Studi di Rumah Zakat Kota Malang," Salam (Jurnal Studi Masyarakat Islam 15, no. 2 (Desember 2012): 200. sosial yang ada di sekitar mereka. ${ }^{7}$

Adapun di dalam konsepsi filantropi Islam, sikap kepedulian yang didasari rasa cinta kepada sesama diwujudkan oleh suatu lembaga atau komunitas tertentu dalam bentuk tindakan menolong orang lain yang membutuhkan dengan cara memberi. Tujuannya adalah untuk kebaikan, mewujudkan kemaslahatan umat demi meningkatkan kualitas hidup masyarakat. ${ }^{8}$ Lebih luas, konsepsi tentang filantropi Islam tidak jauh berbeda dengan perkembangan konsepsi filantropi pada umumnya. Secara spesifik, filantropi Islam didasari pada beberapa hal di bawah ini, ${ }^{9}$ yaitu:

a. Tidak ada dikotomi antara usahausaha spiritual dengan material dalam kehidupan manusia.

b. Menjadi karakter, tujuan, dan fungsi komunitas Muslim (relevan makhluk sosial).

c. Konsep truusteeship mengenai kekayaan dan property.

\section{Pengertian Pendidikan}

Para ahli memberikan definisi yang beragam mengenai pendidikan. Menurut D. Marimba, pendidikan adalah bimbingan atau pembinaan secara sadar oleh pendidik terhadap perkembangan jasmani dan rohani anak didik menuju terbentuknya kepribadian yang utuh. ${ }^{10}$ Sedangan menurut Sudirman $\mathrm{N}$, pendidikan adalah suatu usaha yang dijalankan oleh seseorang atau sekelompok orang untuk mempengaruhi seseorang atau sekelompok orang lain agar menjadi dewasa atau mencapai tingkat hidup dan

${ }^{7}$ Hilman Latief, Melayani Umat: Filantropi Islam dan Ideologi Kesejahteraan Kaum Modernis (Jakarta: PT Gramedia Pustaka Utama, 2010), 36-37.

8 Latief, 17.

9 Abidin, "Manifestasi dan Latensi Lembaga Filantropi Islam dalam Praktek Pemberdayaan Masyarakat: Suatu Studi di Rumah Zakat Kota Malang," 200.

10 D Marimba, Pengantar Filsafat Pendidikan Islam (Bandung: Al-Ma'arif, 1989), 19. 
penghidupan yang lebih tinggi dalam arti mantap. ${ }^{11}$

Adapun menurut Ki Hajar Dewantoro, pendidikan adalah daya upaya untuk memajukan budi pekerti, pikiran, dan jasmani anak agar selaras dengan alam dan masyarakat. ${ }^{12}$

\section{Pengertian Karakter}

Secara terminologi, "karakter" diartikan sebagai sifat manusia pada umumnya yang bergantung pada faktor kehidupannya sendiri. Di dalam Kamus Cerdas Bahasa Indonesia, karakter diartikan sebagai sifat-sifat kejiwaan, akhlak, budi pekerti yang membedakan seseorang dari yang lain, tabiat, watak. ${ }^{13}$ Sejalan dengan itu, Poerwodarminto pun menjelaskan bahwa karakter adalah tabiat, watak sifatsfat kejiwaan, akhlak atau budi pekerti yang membedakan seseorang dengan orang lain. ${ }^{14}$ Definisi yang sejalan lainnya yaitu menurut Hidayatullah, secara harfiah, karakter adalah kualitas atau kekuatan mental atau moral, akhlak, atau budi pekerti yang merupakan kepribadian khusus yang membedakan dengan individu lain. ${ }^{15}$

Lebih lajut, Jalaludin mengemukakan bahwa karakter terbentuk dari pengaruh luar, terbentuk dari asimiliasi dan sosialisasi. Asimilasi berhubungan dengan lingkungan duniawi. Sedangkan sosialisasi menyangkut hubungan antar manusia. Kedua unsur inilah yang membentuk karakter dan karakter

11 Sudirman N, Ilmu Pendidikan (Bandung: Remaja Rosdakarya, 1987), 4.

12 Ki Hajar Dewantoro, Bagian 1 Pendidikan (Yogyakarta: Majelis Luhur Taman Siswa, 1994), 14.

${ }_{13}$ Tim Bahasa Pustaka Agung Harapan, Kamus Cerdas Bahasa Indonesia Terbaru (Bandung: CV Pustaka Agung Harapan, 2003), 300.

14 Amirullah Syarbini, Buku Pintar Pendidikan Karakter: Panduan Lengkap Mendidik Karakter Anak di Sekolah, Madrasah, dan Rumah (Jakarta: Prima Pustaka, 2012), 13.

${ }^{15}$ M Furqon Hidayatullah, Pendidikan Karakter: Membangun Peradaban Bangsa (Surakata: Yuma Pustaka, 2010), 300 . merupakan pola seseorang berhubungan dengan lingkungannya. ${ }^{16}$ Adapun menurut Thomas Lickona, karakter itu terbentuk dari tiga macam bagian yang saling berkaitan, yaitu pengetahuan moral, perasaan moral, dan perilaku moral. ${ }^{17}$ Berdasarkan ketiga komponen tersebut dapat dinyatakan bahwa karakter yang baik didukung oleh pengetahuan tentang kebaikan, keinginan untuk berbuat baik, dan melakukan perbuatan kebaikan. ${ }^{18}$

\section{Pendidikan Karakter}

Dari konsep pendidikan dan karakter yang sudah dijabarkan sebelumnya, maka muncullah istilah pendidikan karakter (character education) atau pendidikan moral (moral education). Zubaedi mengatakan bahwa pendidikan karakter diartikan sebagai upaya penanaman kecerdasan dalam berfikir, penghayatan dalam bentuk sikap, dan pengamalan dalam bentuk perilaku yang sesuai dengan nilai-nilai luhur yang menjadi jati dirinya, diwujudkan dalam interaksi dengan Tuhanya, diri sendiri, masyarakat dan lingkungan. ${ }^{19}$ Donie Koesoema juga mengungkapkan bahwa pendidikan karakter merupakan usaha yang dilakukan secara individu dan sosial dalam menciptakan lingkungan yang kondusif bagi pertumbuhan kebebasan individu itu sendiri. ${ }^{20}$ Fahrur Razi pun menyimpulkan, pendidikan karakter adalah pendidikan yang tidak hanya berorientasi pada aspek

${ }^{16}$ Jalaludin, Psikologi Agama (Jakarta: Grafindo, 1997), 167.

17 Thomas Lickona, Pendidikan Karakter panduan Mendidik Siswa Menjadi Pintar dan Baik (Bandung: Nusa Media, 2008), 72.

18 "Pendidikan Karakter: Pengertian Pendidikan Karakter," diakses 20 Oktober 2017, http://belajarpsikologi.com/pengertian-pendidikankarakter/.

${ }^{19}$ Zubaedi, Desain Pendidikan Karakter: Konsepsi dan Aplikasinya dalam Lembaga Pendidikan (Jakarta: Kencana, 2011), 17.

${ }^{20}$ Doni Koesoeman, Pendidikan Karakter: Strategi Mendidikn Anak di Zaman Global (Jakarta: Grafindo, 2010), 194. 
kognitif saja, akan tetapi lebih berorientasi pada proses pembinaan potensi yang ada dalam diri peserta didik, dikembangkan melalui pembiasaan sifat baik, yaitu berupa pengajaran nilai-nilai karakter. ${ }^{21}$

Selain definisi di atas, Depdiknas (2010) pun memberikan definisi bahwa pendidikan karakter adalah segala sesuatu yang dilakukan guru, yang mampu mempengaruhi karakter peserta didik. Dalam rangka memperkuat pelaksanaan pendidikan karakter, ada 18 nilai-nilai dalam pembangunan pendidikan budaya dan karakter yang dibuat oleh Diknas. Adapun 18 nilai karakter ${ }^{22}$ tersebut, yaitu:

1. Religius

2. Jujur

3. Toleransi

4. Disiplin

5. Kerja keras

6. Kreatif

7. Mandiri

8. Demokratis

9. Rasa ingin tahu

10. Semangat kebangsaan

11. Cinta tanah air

12. Menghargai prestasi

13. Bersahabat

14. Cinta damai

15. Gemar membaca

16. Peduli lingkungan

17. Peduli sosial

18. Tanggung jawab

Nilai-nilai pendidikan karakter harus terintegrasikan ke dalam semua mata pelajaran. ${ }^{23}$ Teori dan konsep di atas

${ }^{21}$ Fahrur Rozi, Model Pendidikan Karakter dan Moralitas Siswa di Sekolah Islam Modern; Studi pada SMP Pondok Pesantren Selamat Kendal (Semarang: IANIN Walisongo, 2012), 6.

22 Pendidikan Karakter bangsa. http:// perpustakaan.kemdiknas.go.id/download/ pendidikan\%20Karakter.pdf. Diakses 26 Oktober 2017.

23 Azkia Muharom Albantani dan Ahmad Madkur, "Integrating Character Education Values In Language Teaching: Why and How," 2016, 8. memiliki relevansi terhadap objek kajian dalam penelitian ini, yaitu filantropi Islam Rumah Sabilillah dan penanaman karakter kepedulian sosial pada siswa di SDIT An Najah. Dengan merujuk pada pengertian yang diungkapkan oleh para ahli di atas, jika dikaji dalam perspektif agama Islam, maka dapat dikatakan bahwa nilai filantropi merupakan sebuah ajakan, tuntunan, atau sebuah ibadah dalam bentuk memberi, melayani, dan mengasosiasikan diri kepada sesama manusia karena kecintaan kepada Allah sehingga dilakukan semata-mata untuk mendapatkan ridho dan rahmat dari- Nya.

Di dalam filantropi terdapat nilai-nilai kepedulian sosial yang diwujudkan pada kebiasaan berderma atau memberi. Dalam hal ini, peneliti melihat bahwa terdapat hubungan yang erat antara filantropi dengan lembaga pendidikan dalam menumbuhkan jiwa karakter peduli anak di SDIT An Najah Jatinom Klaten dengan pendekatan filantropi Rumah Sabilillah.

\section{Hasil Penelitian dan Pembahasan}

\section{Hasil Penelitian}

Berdasarkan hasil wawancara peneliti dengan kepala sekolah SDIT An Najah, Rumah Sabilillah berdiri sejak tahun 2010. Tujuan dibentuknya adalah untuk menjadi wadah bagi seluruh warga sekolah baik guru, karyawan, maupun siswa dalam segala kegiatan yang berbau sosial. ${ }^{24}$ Sejak dirintis pada tahun 2010, Rumah Sabilillah berkembang hingga saat ini. Pada tahun 2016, RS meresmikan kesekretariatannya di lingkungan kampus 1 SDIT An Najah. Hal ini menjadi satu bukti keseriusan sekolah dalam upaya mengembangkan filantropi di lembaga terkait.

${ }^{24}$ Wawancara dengan Khamim Kepala Sekolah SDIT AN Najah Jatinom Klaten. Senin, 23 Oktober 2017. 


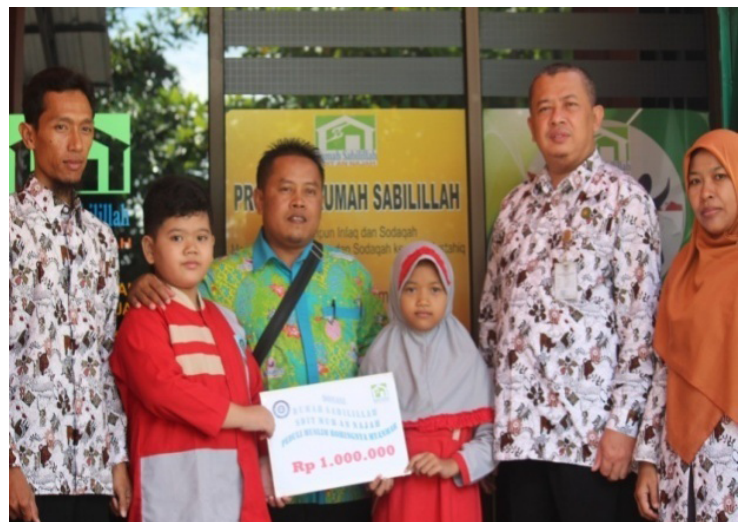

Gambar 1. Peresmian Sekretariat Rumah Sabilillah dan Simbolik Donasi

Peneliti mlihat bahwa lembaga Rumah Sabilillah ini sangat strategis digunakan oleh sekolah sebagai pendekatan untuk menumbuhkan jiwa karakter peduli kepada seluruh peserta didik. Untuk mewujudkan harapan tersebut, maka sekolah bersinergi dengan Rumah Sabilillah dengan tahapan langkah sebagaimana uraian di bawah ini.

\section{a. Tahap Perencanaan}

Di dalam tahap perencanaan ini, terdapat dua langkah penting, yaitu pembentukan program dan sosialisasi program sebagaimana penjelasan di bawah ini;

1) Pembentukan Program

Program yang dibentuk oleh Rumah Sabilillah adalah berkaitan dengan bidang sosial, baik sosial kemasyarakan, sosial keagamaan, maupun sosial pendidikan. Program tersebut dibuat guna untuk mendaratkan sikap peduli anak kepada sesama. ${ }^{25}$ Adapun program Rumah Sabilillah meliputi 5 program unggulan, yaitu:

\section{a) Santunan Fakir Miskin}

Santunan Fakir Miskin adalah gerakan peduli sekolah kepada masyarakatyang berkategorifakiratau miskin. Bantuan ini ditujukan kepada siswa baik intern maupun ekstern

25 Wawancara dengan Khamim. Senin, 23 Oktober 2017.
An Najah serta warga masyarakat umum di lingkungan sekitar An Najah. Bantuan ini diwujudkan baik dalam bentuk uang sebesar 200.000.00 setiap bulan maupun barang berupa sembako untuk kebutuhan hidup sehari-hari.

\section{b) Santunan Yatim Piatu}

Santunan yatim piatu adalah gerakan peduli sekolah terhadap anak-anak yatim piatu. Sasaran dari santunan ini, yaitu anak yatim atau piatu intern maupun ekstern An Najah. Bagi anak luar, secara individu santunan tersebut diberikan dalam bentuk uang tunai sebesar Rp. 200.000.00 per anak setiap bulannya, atau pun bisa juga berupa sembako atau kebutuhan pokok sehari-hari. Di samping itu, satunan anak luar juga menyasar kepada anak-anak panti asuhan yang berada di wilayah kabupaten Klaten, terutama yang berdekatandenganlingungan sekolah. Adapun bagi anak dalam, santunan diberikan dalam bentuk beasiswa.

\section{c) Santunan Lansia}

Santunan Lansia adalah
gerakan peduli sekolah kepada
warga lansia. Bantuan ini merupakan
bentuk kepedulian sekolah kepada
masyarakat di sekitar lingkungan An
Najah maupun masyarakat umum
yang berkategori lansia, yaitu pria
atau wanita yang sudah berusia lanjut
(60 tahun ke atas). Kategori lansia
di sini ialah baik masih produktif
atau tidak produktif dalam bekerja.
Bantuan ini diberikan setiap bulan
sekali dan diwujudkan dalam bentuk
uang sejumlah Rp. 200.000 .00 maupun
sembako atau kebutuhan rumah
tangga untuk keperluan selama
satu bulan.


d) Bantuan Program Pendidikan

Bantuan Program Pendidikan merupakan gerakan kepedulian sekolah terhadap masyarakat dalam rangka memberikan kontribusi untuk penguatan di bidang pendidikan. Ini adalah bentuk praktik dari filantropi pendidikan yang dikembangkan oleh RS. Program ini mengarah pada intern dan ekstern An Najah. Bagi intern, bantuan diberikan dalam bentuk beasiswa bagi anak-anak yang kurang mampu dan berprestasi. Bagi ekster, bantuan diarahkan kepada sekolahsekolah lain dan lembaga pendidikan non formal seperti Madrasah Diniah atau TPA (Taman Pendidikan AlQur'an) di desa-desa sekitar Jatinom. Bantuan tersebut diwujudkan dalam bentuk penguatan sarana dan prasana dalam proses pembelajaran.

e) Rumah Tanggap Bencana

Rumah Tanggap Bencana (RTB) adalah program merespon untuk memberikan bantuan kepada masyarakat yang tertimpa musibah. Berdasarkan wawancara dengan ketua RS, program tanggap bencana ini ditujukan sesuai dengan kompleksitas bencana atau musibah yang menimpa masyarakat baik yang disebabkan oleh alam atau lainnya, misalnya; banjir, tanah longsor, kekeringan, gempa bumi, gunung meletus, rumah roboh, jalan rusak, atau bahkan bencana kemanusian.

\section{2) Sosialisasi Program}

Tahap sosialisasi ini merupakan sebuah bentuk upaya lembaga untuk memberikan pengetahuan tentang program-program Rumah Sabilillah dan pentingnya kepedulian dalam membantu sesama. Adapun sosialisasi tersebut diberikan kepada;

\section{a) Siswa}

Dalam praktiknya, sosialisasi kepada siswa diberikan oleh Tim Marketing Rumah Sabilillah, yaitu para Wali Kelas. Wali kelas memberikan informasi kepada semua siswa tentang program-program yang ada di lembaga Rumah Sabilillah. Di samping itu, para siswa juga dibekali dengan pemahaman tentang pentingnya menjalankan kewajiban zakat dan beramal seperti berinfaq dan bersedekah. Setelah itu, para siswa diberikan motivasi agar mengamalkan praktik ibadah tersebut.

\section{b) Wali Murid}

Sosialisasi kepada wali murid merupakan tindak lanjut dari sosialisasi yang diberikan kepada siswa di sekolah. Harapannya bahwa selain anak, orang tua juga tahu tentang kegiatan atau pun programprogram Rumah Sabilillah sehingga terjadi satu sinergi komunikasi antara Rumah Sabilillah, sekolah, anak, dan orang tua. Adapun sosialisasi tentang program tersebut disampaikanmelalui surat edaran yang dibagikan kepada wali murid dan ditindak lanjuti pada acara parental meeting yang diadakan oleh sekolah setiap satu bulan sekali.

\section{b. Tahap Tindakan}

Sebagai sebuah lembaga filantropi pada umumnya, Rumah Sabilillah bertujuan untukmenghimpun dana sosial berupa zakat, infaq, dan sedekah serta menyalurkannya kepada yang berhak (mustahiq). Dalam tahap ini, Rumah Sabilillah memiliki tiga pekerjaan utama, yaitu mengumpulkan atau menggalang dana (fundraising), mengelola (management), dan mentasyaraufkannya (distribution). 
1) Pengumpulan/Penggalangan Dana (fundraising)

Berdasarkan wawancara peneliti dengan Kepala Sekolah SDIT An Najah, Rumah Sabilillah mengandalkan dana filantropi berupa zakat, infaq, dan sedekah yang dihimpun dari seluruh warga sekolah mulai dari guru, karyawan, siswa, dan wali murid. ${ }^{26}$ Dalam proses penggalangan dana filantropi tersebut, diperlukan strategi yang baik agar para donatur menyalurkan donasinya melalui lembaga yang dikelola. Michael Norton mengungkapkan bahwa strategi fundraising merupakan tulang punggung dari kegiatan fundraising ${ }^{27}$ sehingga sangat diperlukan oleh sebuah organisasi dalam menjalankan kegiatannya. Joyce Young pun mengungkapkan bahwa suatu organisasi yang menjalankan organisasinya tanpa strategibagai melakukan perjalanan tanpa peta. ${ }^{28}$ Adapun menurut Hamid Abidin, terdapat 4 aspek yang ada dalam strategi fundraising (dikenal siklus fundraising), yaitu; (1) identifikasi calon donatur, (2) penggunaan metode fundraising, (3) pengelolaan dan penjagaan donatur, (4) monitoring dan evaluasi fundraising. ${ }^{29}$

Sebagaimana disebutkan sebelumnya, filantropi Rumah Sabilillah bersumber dari dana zakat, infaq, dan sedekah dari para donatur. Dalam praktik penggalangan dana tersebut, RS melakukan empat aspek sebagai bentuk dari strategi fundraising-nya, yaitu:

\section{a) Identifikasi Donatur}

$$
\text { Identifikasi ini merupakan }
$$

${ }^{26}$ Wawancara dengan Khamim

27 Michael Norton, Menggalang Dana: Penuntun untuk Lembaga Swadaya Masyarakat dan Organisasi Sukarela di Negara-negara Selatan (Jakarta: Yayasan Obor Indonesia, 2002), 51.

${ }^{28}$ Joyce Young, dkk, Menggalang Dana untuk Organisasi Nirlaba (Jakarta: PT. Ina Publikatama, 2007), 124.

${ }^{29}$ Hamid Abidin, dkk, Membangun Kemandirian Perempuan Potensi dan Pola Derma untuk Memberdayakan Perempuan serta Strategi Penggalangannya (Depok: Piramedia, 2009), 134-51. langkah yang dilakukan oleh RS dalam menentukan siapa dan bagaimana profil dari potensial donatur yang akan digalangnya. Berdasarkan hasil wawancara kepada Tim Sumber Daya dan Marketing RS, penggalagan dana filantropi RS memfokuskan target atau sasarannya pada perorangan, yaitu dari intern sekolah, yaitu guru, karyawan, dan siswa atau wali murid di SDIT An Najah. ${ }^{30}$

\section{b) Metode Fundraising}

Metode fundraising merupakan sebuah langkah untuk menentukan bagaimana cara melakukan pendekatan terhadap donatur RS. Hamidah mengungkapkan bahwa pendekatan ini perlu dilakukan karena akan menjadi penentu keberhasilan perolehan dana yang sebesar-besarnya dari para donatur. Adapun cara yang dilakukan RS, yaitu:

\section{(1) Face to Face}

Face to face merupakan cara penggalangan dana yang dilakukan RS secara langsung kepada para guru dan karyawan di lembaga An Najah untuk mau menyumbangkan 2,5\% dari gaji yang diterimanya setiap bulan sebagai bentuk zakat profesi atau zakat penghasilan seorang guru di sekolah. Penggalangan dana ini diawali terlebih dahulu dengan menyampaikan program-program RS yang telah dibentuk dan dijalankan.

(2) Direct Mail

Direct mail merupakan penawaran tertulis untuk menyumbang yang didistribusikan melalui surat. ${ }^{31}$ Cara ini dilakukan RS

${ }^{30}$ Wawancara kepada Hamidah sebagai Ketua Tim Sumber Daya dan Marketing Rumah Sabilillah. Selasa, 24 Oktober 2017.

31 Muhsin Kalida, Fundraising Taman Bacaan Masyarakat (TBM) (Yogyakarta: Cakruk, 2012), 157-59. 
untukmenggalangdanadariparasiswa dengan terlebih dahulu memberikan surat pemberitahuan dari RS kepada semua wali murid di SDIT An Najah. Surat tersebut biasanya berisi tentang pemberitahuan programprogram sosial RS baik yang sudah ditentukan seperti lima program yang sudah disebutkan maupun program yang sifatnya insidental, seperti penggalangan dana kemanusian atau pembangunan masjid. Pemberitahuan program tersebut dikuatkan dengan dasar keagamaan yang jelas dan ajakan kepada wali murid untuk menyisihkan sebagian hartanya agar disumbangkan melalui lembaga.

Di RS, cara di atas digunakan untuk menggalang infaq bulanan, yaitu infaq yang diberikan oleh siswa atau pun wali murid SDIT An Najah setiap satu bulan sekali melalui Kartu Sabilillah dan Kencleng (Tabungan Akhirat) yang disediakan oleh lembaga untuk dibawa pulang di awal bulan dan dibawa ke sekolah pada akhir bulan untuk didonasikan ke RS. Cara ini mempermudah proses penyaluran donasi dari para siswa atau pun wali murid.

\section{(3) Special Event}

Specialevent ialah penggalangan dana dengan mengadakan kegiatankegiatan, atau menggelar acara-acara khusus, atau memanfaatkan acaraacara yang dihadiri banyak orang untuk menggalang dana. ${ }^{32}$ Dalam hal ini, RS memanfaatkan kegiatankegiatan yang dibuat oleh sekolah baik yang melibatkan guru, karyawan, siswa, maupun wali murid untuk melakukan penggalangan dana. Di antara sumber dana dan kegiatan tersebut, yaitu:

\footnotetext{
${ }^{32}$ Kalida, Fundraising Taman Bacaan Masyarakat
}

(a) Infaq mingguan, yaitu infaq yang diberikan oleh guru dan karyawan pada saat dilaksanakan rapat monitoring dan evaluasi (monev) rutinan setiap minggu sekali di sekolah.

(b) Infaq jumat, yaitu infaq yang dimasukkankedalamkotakamal dari para jamaah (guru, karyawan, siswa) shalat jum'at yang diselenggarakan di Mushola lingkungan sekolah.

(c) Infaq Ramadhan, yaitu infaq yang diberikan oleh murid dan wali murid melalui kotak amal hasil dari hasta karya peserta didik yang dibawa pulang pada saat menjelang bulan Ramadhan dan dibawa ke sekolah pada awal masuk usai libur lebaran (idul fitri) untuk didonasikan ke Rumah Sabilillah. Pengisian kotak amal di rumah ini adalah sebagai media pembelajaran bagi semua siswa untuk membiasakan berderma sekaligus memanfaatkan dengan baik moment di bulan Ramadhan untuk memperbanyak amal shaleh dengan berinfaq.

(d) Infaq Parental Meeting, yaitu infaq hasil kotak amal yang diberikan oleh wali murid pada saat kegiatan parental meeting wali murid yang diadakan oleh sekolah setiap satu bulan sekali.

(e) Infaq Class Meeting, yaitu infaq yang diberikan oleh siswa pada salah satu kegiatan di class meeting yang bernama pasar ekonomi Islam. Pasar ekonomi Islam diadakan oleh sekolah dalam rangka memberikan pendidikan berkaitan dengan praktik ekonomi Islam. Dalam kegiatanya, sekolah memberikan himbauan kepada seluruh siswa untuk membuat beraneka macam makanan dan minuman di rumah 
bersama orang tua lalu dibawa ke sekolah untuk dijual kepada warga sekolah sendiri. Seluruh siswa membuat stand market di halaman sekolah yang yang disediakan oleh panitia class meeting sesuai dengan kelasnya masing-masing. Secara sederhana, penjual adalah seluruh siswa, dan pembeli adalah seluruh warga sekolah, baik siswa sendiri, guru, dan seluruh karyawan. Hasil penjualan tersebut menjadi milik kolektif anak sesuai dengan kelasnya. Uang itu dijadikan kas kelas yang digunakan untuk keperluan kelas dan sebagian disisihkan untuk diinfaqkan kepada Rumah Sabilillah. Yang mengesankan ialah sebagian besar kelas biasanya menghendaki seluruh hasil penjualan tersebut untuk diinfaqkan kepada Rumah Sabilillah sebagai bentuk kepedulian mereka kepada orang-orang yang membutuhkan.

(4) Campaign

Campaign yaitu upaya
penggalangan dana dengan
kampanye melalui berbagai media
internet, media elektronik, atau pun brosur yang digunakan sebagai komunikasi dan promosi program lembaga atau pun merawat donatur. ${ }^{33}$ Dalam hal ini, RS merancang strategi penggalangan dana dengan membuat Rumah Sabilillah Online. RS Online ini merupakan upaya lembaga dalam memanfaatkan media sosial sebagai sarana komunikasi dan promosi program-program kepada masyarakat luas. Adapun media sosial yang sudah dibuat dan akan dimanfaatkan secara maksimal ke depannya, yaitu Facebook, WhatsApp, Instagram, dan Blog. Saat ini, Rumah Sabilillah sedang dalam proses pembuatan Web. Untuk RS sendiri, penggunaan media sosial ini sudah didukung dengan adanya fasilitas Wifi di sekolah.

c) Pengelolaan dan Penjagaan Donatur

Pengelolaan donatur sangat penting dilakukan dengan tujuan meningkatkan jumlah sumbangan, mengarahkan donatur untuk menyumbang, pada program tertentu, dan meningkatkan status dari penyumbang tidak tetap menjadi penyumbang tetap. Sementara penjagaan donatur dapat dilakukan dengan kunjungan hangat, mengirimkan informasi, memberikan layanan kepada donatur, melibatkan donatur dalam berbagai kegiatan, mengirimkan hadiah, atau membantu memecahkan persoalan donatur. Adapun langkah yang sudah dilakukan oleh RS dalam upaya mengelola dan menjaga donatur adalah dengan mengirimkan segala informasi program-program yang sudah dijalankan kepada para donatur sekaligus memberikan laporan pendonasian kepada para mustahiq sebagai laporan pertanggungjawaban lembaga dengan menggunakan media sosial seperti WhatsApp. Di samping itu, RS selalu melibatkan para donatur, khususnya siswa, guru, dan karyawan dalam proses pentasyarufan dana bantuan kepada masyarakat. Hal ini sekaligus sebagai satu langkah untuk mengajak mereka secara langsung melihat dan merasakan kondisi para mustahiq yang sebenarnya. Hal ini dapat menumbuhkan rasa cinta kasih dan meningkatnya jiwa kepedulian yang semakin tinggi hingga mengetuk para donatur untuk berderma kepada sesama malalui lembaga.

\footnotetext{
${ }^{33}$ Kalida.
} 
d) Monitoring dan Evaluasi Fundraising

$$
\text { Monitoring dan evaluasi }
$$
fundraising ini merupakan upaya RS dalam memantau bagaimana proses dilakukannya dari kegiatanfundraising serta menilai afektivitasnya. Hal ini dilakukan untuk menilai seberapa efektiv upaya yang dilakukan, memastikanapakahadapermasalahan dalam pelaksanaannya serta seberapa besar pencapaiannya terhadap target yang telah dilakukan. Dalam pengalaman RS selama ini, upaya penggalangan dana dari donatur intern sudah sangat efektif. Namun, yang menjadi kelemahan RS adalah belum maksimalnya penggalangan dana dari warga luar sekolah atau masyarakat umum. Peneliti melihat bahwa hal ini disebabkan karena lembaga RS merupakan lembaga baru yang tumbuh di tengahtengah lembaga sosial yang sudah menjamur di berbagai wilayah di Indonesia sehingga popularitas dan pengaruhnya belum terlihat di dalam masyarakat secara luas. Maka dari itu, diperlukan upaya yang strategis dan inofativ dalam mengembangkan lembaganya supaya tidak tenggelang di tengah menjamurnya lembagalembaga filantropi di Indonesia, terutama dalam membuat inovasi program dalam memberikan solusi terhadap problem sosial yang semakin kompleks di masyarakat.

\section{2) Pengelolaan Dana (management) dan Pentasyarufan (distribution)}

Untuk memobilisasi dana

filantropi agar terkelola secara sistematis dan terstruktur yang kemudian dapat dimanfaatkan sebagaimana mestinya, maka mutlak rasanya diperlukan suatu lembaga yang menjadi mediator antara si kaya dengan si miskin. Dalam perundang-undangan Nomor 38 Tahun 1999, diakui adanya dua jenis organisasi pengelola zakat dan dana filantropi pada umumnya, yaitu (1) Badan Amil Zakat (BAZ) yaitu organisasi pengelola zakat yang dibentuk oleh pemerintah, dan (2) Lembaga Amil Zakat (LAZ), yaitu organisasi pengelola zakat yang diprakarsai oleh swasta yang mendapat izin resmi dari pemerintah. Salah satu lembaga filantropi yang diprakarsai oleh swasta dan sudah mendapat izin pemerintah setempat, yaitu Rumah Sabilillah.

Sebagaimana di jelaskan di atas bahwa dana filantropi Rumah Sabilillah berupa zakat, infaq, dan sedekah. Dana ini berasal dari intern lembaga An Najah. Dana intern yang dimaksud ialah berasal dari seluruh warga sekolah dari mulai guru, karyawan, siswa, dan wali murid. RS menjadi wadah filantropi tersistem di sekolah dalam hal pengelolaan dana tersebut. Dana yang telah terkumpul kemudian disalurkan kepada mereka yang berhak sesuai dengan programprogram yang dicanangkan sebagaimana lima program unggulan yang telah dijelaskan penulis sebelumnya, yaitu Santunan Fakir Miskin, Santunan Yatim Piatu, Santunan Lansia, Rumah Tanggap Bencana (RTB), dan Bantuan Program Pendidikan (BPP). Dalam proses pentasyarufan, Rumah Sabilillah selalu melibatkan siswa. Hal ini dilakukan agar mereka merasakan secara langsung bagaimana indahnya memberi kepada sesama sehingga akan tumbuh jiwa sosial pada diri mereka yang mewujud pada kebiasaan memberi sebagai bentuk sikap kepedulian.

\section{Pembahasan}

\section{A. Implementasi Penanaman Karakter Kepedulian Sosial pada Siswa}

Proses penanaman karakter kepeduliaan pada siswa di SDIT An Najah dilakukan dengan pendekatan melalui 
aktivisme filantropi Islam Rumah Sabilillah. Adapun implementasinya dapat dilihat baik pada tahap perencanaan maupun tindakan dalam kegiatan filantropi Islam Rumah Sabilillah.

\section{1) Tahap Perencanaan}

Di tahap ini, terdapat dua langkah penting Rumah Sabilillah, yaitu;

\section{a) Pembentukan Program}

Program yang dibentuk Rumah Sabilillah menjadi wadah bagi siswa untuk menyalurkan kepedulian sosialnya dengan memberi yang diwujudkan dengan berzakat, berinfaq, dan bersedekah.

b) Sosialisasi Program

Sosialisasi menjadi tahap awal dalam penanaman karakter kepeduliaan siswa. Sebab, pada tahap ini siswa mendapat beberapa hal penting, yaitu:

(1) Pengetahuan tentang program sosial Rumah Sabilillah

(2) Pengetahuan tentang kewajiban sebagai seorang Muslim untuk menyisihkan sebagian harta yang dimiliki kepada orang lain yang membutuhkan dengan praktik berzakat, berinfaq, dan bersedekah

(3) Pengetahuan tentang pentingnya praktik ibadah zakat, infaq, dan sedekah bagi kesejahteraan orang lain

(4) Motivasi untuk melakukan kegiatan zakat, infaq, dan sedekah karena kecintaan kepada sesama dan sebagai wujud dalam menjalankan perintah Allah SWT

\section{2) Tahap Tindakan}

Di tahap ini, sekolah menumbuhkanjiwa peduli sosial siswa dalambentukpraktikmemberimelalui program-program yang dibentuk oleh
Rumah Sabilillah. Jiwa kepedulian sosial tersebut disalurkan melalui aktivisme filantropi Rumah Sabilillah, yaitu pada tahap pengumpulan/ penggalangan dana, dan dikuatkan dengan tahap pentasyarufan.

a) Pengumpulan/penggalangan dana (fundraising)

Melalui rangkaian kegiatan sekolah, Rumah Sabilillah melakukan penggalangan dana kepada warga sekolahtermasuksiswadenganstrategi dan inovasi fundraising. Penggalangan dana tersebut sekaligus sebagai upaya sekolah dalam menyalurkan pembiasaan anak untuk berinfaq dan bersedekah dengan tahap mingguan, bulanan, dan tahunan sebagaimana uraian di bawah ini:

(1) Infaq Mingguan

Infaq mingguan, yaitu infaq yang diberikan oleh siswa pada saat kegiatan shalat Jumat di Mushola lingkungan sekolah melalui kotak amal/kotak infaq yang disediakan oleh sekolah. Infaq yang terkumpul dihitung sendiri oleh siswa yang menjadi petugas penghitung infaq yang ditunjuk dan diumumkan kepada seluruh jamaah shalat Jumat agar mereka tahu berapa jumlah infaq yang terkumpul. Hasil infaq tersebut kemudian diserahkan secara langsung oleh siswa sendiri kepada guru yang ditunjuk sebagai bendahara Mushola yang nantinya siserahkan kepada bendahara Rumah Sabilillah.

(2) Infaq Bulanan

Infaqbulanan, yaitupembiasaan berinfaq siswa yang diberikan setiap satu bulan sekali. Infaq tersebut disalurkan melalui media Kartu Rumah Sabilillah. Namun, sejak tahun 2017, Kartu Rumah Sabilillah diganti dengan Kencleng Rumah Sabilillah 
yang dikenal dengan "Tabungan Akhirat".

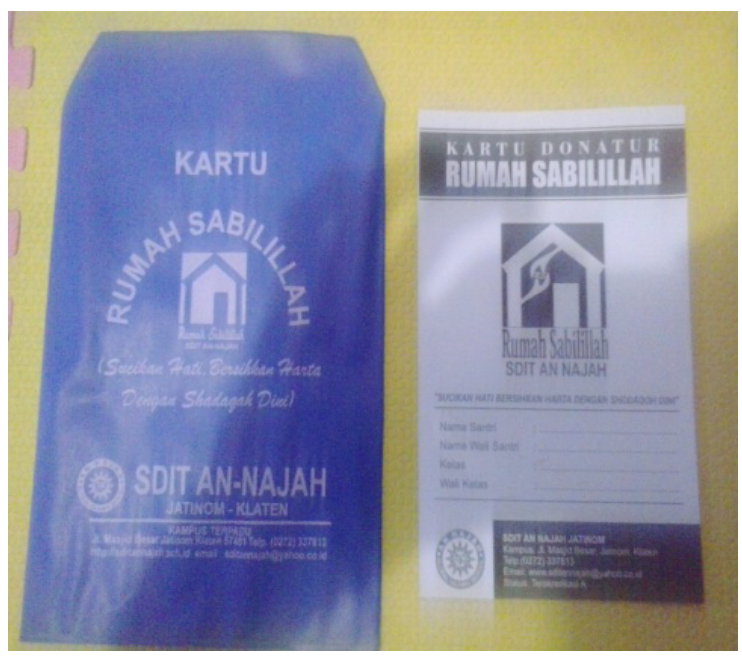

Gambar 2. Kartu Rumah Sabilillah (20102017)
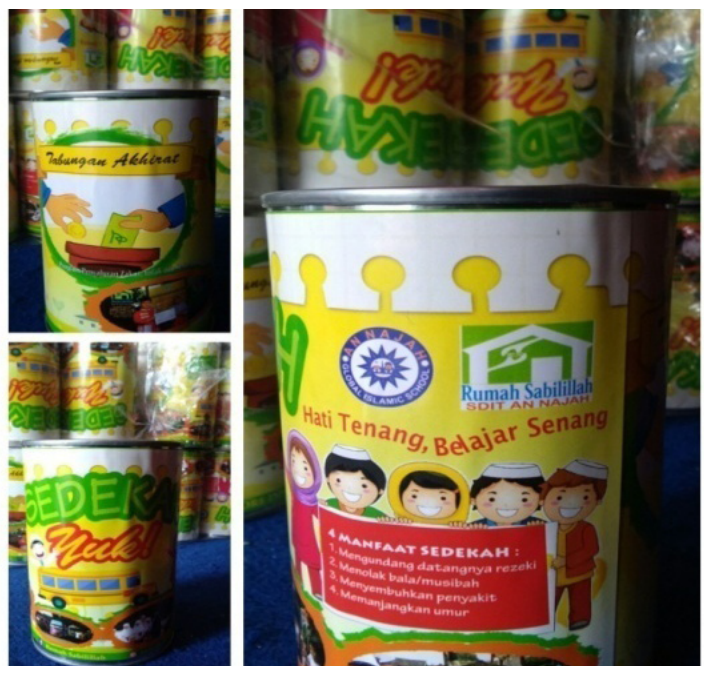

Gambar 3. Tabungan Akhirat (2017)

Tabungan Akhirat di atas dibagikan kepada seluruh siswa untuk dibawa pulang setiap awal bulan sebagai media pembiasaan berinfak di rumah setiap hari. Untuk memotivasi agar siswa gemar menabung untuk akhirat, maka tabungan didesain sedemkian rupa dengan memasukkan konten-konten atau tulisan seperti:
(a) Tabungan Akhirat
(b) Sedekah Yuk, "Hati Tenang, Belajar Senang"
(c) Empat manfaat sedekah:

- $\quad$ Mengundang datangnya rezeki

- Menolak bala/musibah

- Menyembuhkan penyakit

- Memajagkan umur

(d) Lima program Rumah Sabilillah

Tabungan tersebut kemudian dibawa ke sekolah setiap akhir bulan. Hasil tabungan tersebut dihitung bersama-sama di kelas bersama wali kelas masing-masing. Dengan demikian antara siswa satu dengan siswa lainnya bisa tahu hasil infaq yang terkumpul selamasatubulan sehingga mereka berlombalomba dalam kebaika untuk meningkatkan infaqnya dikemudian hari. Hasil infaq siswa tersebut dikumpulkan kepada wali kelas lalu diserahkan kepada bendahara Rumah Sabilillah untuk direkap dan dikelola.

\section{(3) Infaq Tahunan}

Infaq tahunan, yaitu pembiasaan berinfaq siswa yang diberikan setiap satu tahun sekali menyesuaikan dengan kegiatan yang diadakan sekolah, yaitu kegiatan class meeting dan kegiatan Ramadhan.

(a) Infaq Class Meeting

Pasar ekonomi Islam merupakan serangkaian kegiatan class meeting yang diadakan sekolah. Tujuan dari kegiatan ini adalah untuk memberikan pengetahuan kepada anak tentang ekonomi Islam melalui praktik berdagang. Kegiatan ini memberikan pendidikan kepada anak bahwa harta yang dimilikinya adalah titipan dari Allah, dan sebagian harta yang mereka miliki ada hak orang lain. Jumlah infaq dari seluruh santri dari kegiatan ini rata-rata 1 hingga 2 juta per tahun.

\section{(b) Infaq Ramadhan}

Ramadhan adalah bulan yang mulia. Moment bulan Ramadhan mengajak siswa untuk berlomba-lomba dalam kebaikan, termasuk memperbanyak amal sedekah. Dengan kotak amal hasil hasta karya yang buat oleh siswa sendiri diisi di rumah selama bulan Ramadhan berlangsung. Ini adalah pembiasaan sedekah selama bulan Ramadhan penuh. Hasil dari infaq tersebut 
dibawa oleh siswa ke sekolah dan diserahkan kepada wali kelas masing-masing untuk disalurkan melalui Rumah Sabilillah. Hasil dana yang masuk dari infaq Ramadhan siswa setiap tahunnya rata-rata sejumlah 15 hingga 20 juta.

\section{b) Pentasyarufan (distribution)}

Dana infaq dan sedekah yang berasal dari siswa baik yang mingguan, bulanan, maupun tahunan dikelola secara sistemik dan ditasyarufkan sesuai dengan 5 program unggulan Rumah Sabilillah, yaitu:

(1) Santunan Fakir Miskin

Santunan fakir miskin diperuntukkan kepada anak dalam dan anak luar sekolah. Bantuan untuk anak dalam diwujudkan dengan subsidi biaya SPP sebesar Rp. 200.000.00. Sedangkan untuk anak sebesar Rp. 200.000/bulan. Bantuan tersebut diwujudkan dalam bentuk sembako atau alat perlengkapan sekolah. Artinya menyesuaikan dengan kebutuha anak.

(2) Santunan Yatim Piatu

Santunan yatim piatu diperuntukkan kepada anak dalam dan anak luar sekolah. Untuk anak dalam, bantuan duwujudkan dalam bentuk subsidi SPP sebesar Rp. 200.000.00/bulan. Untuk anak luar menyesuaikan dengan kebutuhan anak tersebut.

(3) Santunan Lansia

Santunan lansia diperuntukkan kepada para lansia yang berada di sekitar lingkungan sekolah atau daerah Jatinom.

\begin{tabular}{|c|c|c|c|}
\hline Tahun Ajaran & Jumlah Lansia & Nominal & Wujud \\
\hline 2010/2011 & 4 & \multirow{6}{*}{ Rp. 200.000/bulan } & \multirow{6}{*}{$5^{5^{5_{0}^{5}}}$} \\
\hline 2011/2012 & 4 & & \\
\hline $2012 / 2013$ & 4 & & \\
\hline 2013/2014 & 4 & & \\
\hline $2014 / 2015$ & 4 & & \\
\hline $2015 / 2016$ & 4 & & \\
\hline
\end{tabular}

\begin{tabular}{|l|l|l|}
\hline $2016 / 2017$ & 5 \\
\hline $2017 / 2018$ & 6 & \\
\end{tabular}

Tabel 1. Data diambil dari laporan tahunan Rumah Sabilillah

(4) Bantuan Program Pendidikan (BPP) Bantuan program pendidikan diperuntukkan kepada anak dalam sekolah. Berikut daftar jumlah anak dan nominal bantuan yang sudah ditasyarufkan dari tahun 2010 sampai 2017:

\begin{tabular}{|l|c|c|c|}
\hline Tahun Ajaran & Jumlah Anak & Nominal & Wujud \\
\hline $2010 / 2011$ & 4 & & \\
\hline $2011 / 2012$ & 5 & & \\
\hline $2012 / 2013$ & 7 & & \\
\cline { 1 - 2 } $2013 / 2014$ & 8 & \multirow{2}{*}{ Rp. 200.000/bulan } & Subsidi SPP \\
\hline $2014 / 2015$ & 9 & & \\
\hline $2015 / 2016$ & 10 & & \\
\hline $2016 / 2017$ & 10 & & \\
\hline $2017 / 2018$ & 15 & & \\
\hline
\end{tabular}

Tabel 2. Data diambil dari laporan tahunan Rumah Sabilillah

\section{Keterangan:}

Kategori anak penerima BPP, yaitu:

(a) Fakir/miskin

(b) Yatim/piatu/yatim piatu

(c) Berprestasi

(d) Anak korban broken home

(e) Kondisiorang tua sedang mengalami bangkrut dalam usaha

(5) Rumah Tanggap Bencana (RTB)

Dalam program ini Rumah Sabilillah memberikan bantuan kepada masyarakat yang terkena musibah, seperti rumah roboh, rumah kebakaran, korban gunung meletus, gempa bumi, kekeringan, atau bahkan bantuan kemanusiaan seperti bantuan untuk Palestina, bantuan untuk Rohingya, dan bantuan kemanusiaan lainnya.

Peneliti melihat ada hal menarik dalam proses pentasyarufan dana filantropi Rumah Sabilillah, 
yaitu pelibatan seluruh warga sekolah dari mulai guru, karyawan, termasuk juga siswa. Secara langsung, siswa ikut berpartisipasi mentasyarufkan dana bantuan kepada para mustahiq Rumah Sabilillah, baik kepada fakir miskin, lansia, korban rumah roboh, korban rumah kebakaran, warga yang mengalami kekeringan, dan lain sebagainya.

Beragam cara yang digunakan oleh Rumah Sabilillah dalam pelibatan siswa pada proses pentasyarufan dana filantropi yang terkumpul, antara lain yaitu;

\section{(1) Moment Ramadhan}

Di bulan Ramadhan ada salah satu kewajiban bagi setiap Muslim untuk mengeluarkan zakat. Peran Rumah Sabilillah di sini ialah sebagai lembaga filantropi yang menerima dan mentasyarufkan zakat fitri kepada yang berhak menerimanya. Maka, langkah Rumah Sabilillah dan sekolah ialah membuat surat edaran kepada wali murid untuk menghimbau dan mengarahkan agar menyalurkan zakatnya melalui sekolah. Dana filantropi berupa zakat yang terkumpul kemudian dikelola oleh Rumah Sabilillah untuk ditasyarufkan kepada yang berhak menerimanya. Adapun penyalurannya ialah kepada warga sekitar lingkungan sekolah dan daerah binaan Rumah Sabilillah yang berada di sekitar wilayah Jatinom.

Yang menarik di sini ialah pada moment pentasyarufan di daerah binaan Rumah Sabilillah. Dalam proses pentasyarufannya, Rumah Sabilillah menyesuaikan dengan program outing sekolah, yaitu semalam bersama warga kurang mampu. Dalam kegiatan ini, ratusan siswa SDIT An Najah diajak untuk mentasyarufkan zakat dan menginap di rumah-rumah warga yang kurang mampu di daerah binaan. Tujuannya antara lain yaitu;

(a) Membina kepekaan sosial siswa melalui interaksi dan sosialisasi secara langsung dengan warga masyarakat.

(b) Memberikan pendidikan mengalami kepada siswa dengan mengetahui dan merasakan secara langsung hidup bersama warga kurang mampu

(c) Memberikan pendidikan karakter kepada siswa untuk peduli kepada sesama.

(d) Mengetuk hati mereka supaya selalu bersyukur ketika dalam kondisi berkecukupan dan bersabar dikala kurang.

(2) Moment PHBI (Peringatan Hari Besar Islam)

Di SDIT An Najah, setiap tahun selalu mengadakan peringatan 1 Muharam sebagai tahun baru Islam denga tema "Spirit Muharam, Teguhkan Hati Kuatkan Solidaritas Islam". Dalam peringatan ini, sekolah mengadakan outing siswa ke daerah yang mengalami kekeringan. Tujuannya yaitu memberikan bantuan air bersih yang dibarengidengan shalat istisqo' bersama warga setempat. Ini adalah kegiatan sosial dan keagamaan untuk memupuk rasa solidaritas siswa kepada warga masyarakat. Kegiatan ini merupakan agenda yang hampir setiap tahun dilakukan oleh sekolah dengan dukungan dana filantropi Rumah Sabilillah.

(3) Moment Idul Adha Idul Adha adalah hari raya umat Islam. Rumah Sabilillah membuat program bernama QSM (Qurban Spirit of Moment), yaitu tebar hewan kurban di sekolah dan desa-desa binaan. Daerah binaan berada di wilayah Jatinom Barat dekat dengan lereng gunung Merapi. 
Daerah ini merupakan daerah yang penduduknyarata-ratakurangmampu dan kesadaran untuk berkurban pun kurang. Oleh karena itu, untuk memupuk kesadaran pentingnya berkurban sekaligus sebagai bentuk perhatian kepada mereka, maka RS mengadakan kegiatan tebar hewan Qurban. Kegiatan penyembelihan dilakukan di dua tempat, yaitu di sekolah dan di desa binaan. Setelah diembelih, siswa bersama-sama mentasyarufkan daging hewan kurban kepada warga masyarakat.

(4) Santunan Lansia

Menyantuni lansia adalah program bulanan Rumah Sabilillah. Sebagai upaya memberikan pendidikan tentang kepedulian terhadap kaum lansia, maka siswa diajak untuk mentasyarufkan sembako kepada mereka. Proses pentasyarufan ini memberikan pendidikan kepada siswa tentang pentingnya berbagi, menghormati orang tua, mensejahterakan kaum yang sudah tidak produktif dalam bekerja. Melihat kaum lansia yang tua renta akan menggugah hati para siswa untuk berfikir kelak di hari tua. Oleh karena itu, di masa usia dini hingga beranjak dewasa kelak, mereka akan menggunakan waktu dengan sebaikbaiknya bekal kelak di hari tua.

(5) Bantuan Rumah Roboh dan Kebakaran

RTB menjadi representasi dari gerakan peduli sekolah terhadap bencana-bencana yang menimpa warga masyarakat seperti rumah roboh, kebakaran, dan musibah lainnya. Musibah-musibah semacam ini tentu memberikan kerugian kepada warga yang tertimpa. Untuk menumbuhkan jiwa kepedulian sosialnya, maka siswa diajak mentasyarufkan dana bantuan yang berupa sembako, peralatan rumah tangga, atau kebutuhan-kebutuhan lainnya sebagai wujud solidaritas kepada sesama.

\section{B. Efektivitas Pendekatan Filantropi Rumah Sabilillah terhadap Peningkatan Karakter Kepedulian Sosial Siswa}

Perlu diketahui bahwa jumlah siswa di SDIT An Najah saat ini (2017) yaitu 617 siswa. ${ }^{34}$ Dengan kepeduliannya, mereka menjadi donatur terbesar Rumah Sabilillah setiap tahunnya dari warga sekolah yang ada. Jumlah rata-rata dana filantropi Rumah Sabilillah dari siswa yang masuk dapat dilihat sebagaimana tabel di bawah ini.

\begin{tabular}{|c|l|l|}
\hline \multicolumn{2}{|c|}{ Dana Filantropi Rumah Sabilillah dari Siswa SDIT An Najah } \\
\hline \multirow{2}{*}{ No } & \multicolumn{1}{|c|}{ Sumber } & \multicolumn{1}{|c|}{ Jumlah Rata-rata Pemasukan } \\
\hline \multirow{2}{*}{1} & Infaq Mingguan & \\
\cline { 2 - 3 } & a. Infaq Jumat & Rp. 40.000 .00 - 50.000.00 \\
\hline \multirow{2}{*}{2} & Infaq Bulanan & \\
\cline { 2 - 3 } & a. Tabungan Akhirat & Rp. $4.000 .000 .00-6.000 .000 .00$ \\
\hline \multirow{2}{*}{3} & Infaq Tahunan & \\
\cline { 2 - 3 } & a. Infaq Class Meeting & Rp. $1000.000 .00-2000.000 .00$ \\
\cline { 2 - 3 } & b. Infaq Ramadhan & Rp. 20.000.000.00 - 25.000.000.00 \\
\hline
\end{tabular}

Tabel 3. Data diambil dari Laporan bendahara RS

Berdasarkan wawancara peneliti dengan Kepala Sekolah bahwa dari tahun pertama pendirian Rumah Sabilillah hingga tahun 2017 ini, dana filantropi yang masuk dari siswa selalu mengalami kenaikan. ${ }^{35}$ Hal ini tidak lepas dari strategi sekolah dan Rumah Sabilillah dalam memberikan pendidikan karakter peduli sosial sebagaimana diungkapkan sebelumnya pada tahap perencanaan dan tindakan. Pada kedua tahap tersebut, strategi sosialisasi, strategi fundraising, dan strategi pentasyarufan menjadi kunci penentu keberhasilan

${ }^{34}$ Wawancara dengan Yusuf Rulianto (Pegawai Tata Usaha SDIT An Najah). Selasa, 24 Oktober 2017.

35 Wawancara dengan Khamim. Senin, 23 Oktober 2017. 
penanaman karakter peduli sosial siswa di SDIT An Najah. Oleh karenanya, karakter peduli sosial yang tertanam mampu menggerakkan hati para siswa untuk gemar memberi yang diwujudkan dengan keaktivan berzakat, infaq, dan sedekah melalui Rumah Sabilillah. Dengan demikian, semakin besar dana filantropi yang masuk, maka akan semakin banyak pula santunan/bantuan yang diberikan kepada para mustahiq melalui 5 program utama Rumah Sabilillah. Perlu diketahui bahwa karena meningkatnya dana filantropi yang masuk, maka bantuan tidak hanya terbatas pada lima program tersebut, akan tetapi sudah melebar, yaitu pada bantuan terhadap pembangunan masjid di wilayah Jatinom dan sekitarnya.

\section{Kesimpulan}

Implementasi penanaman karakter kepedulian sosial siswa di SDIT An Najah dilakukan melalui strategi sosialisasi, strategi fundraising, dan strategi pentasyarufan dalam kegiatan filantropi Islam Rumah Sabilillah.

Pendekatan Filantropi Islam Rumah Sabilillah mampu meningkatkan karakter kepedulian sosial siswa di SDIT A Najah, yang dibuktikan dengan beberapa hal yaitu; meningkatnya dana filantropi Rumah Sabilillah, bertambahnya para mustahiq yang mampu disantuni, dan melebarnya penggunaan dana filantropi yang tidak hanya terbatas pada lima program unggulan Rumah Sabilillah, tetapi juga mampu memberikan bantuan kepada pembangunan masjid di wilayah kecamatan Jatinom dan sekitarnya.

\section{Daftar Pustaka}

Abidin, Zaenal. "Manifestasi dan Latensi Lembaga Filantropi Islam dalam Praktek Pemberdayaan Masyarakat: Suatu Studi di Rumah Zakat Kota Malang." Salam (Jurnal Studi Masyarakat Islam 15, no. 2 (Desember 2012).
Ahmadi, Abu. Sosiologi Pendidikan. Jakarta: PT Renika Cipta, 2007.

Akla. “Desain Pembelajaran Bahasa Arab berbasis Penanaman Karakter untuk Anak Usia Dini." Elementary: Jurnal Ilmiah Pendidikan Dasar 3, no. 2 (2017).

Albantani, Azkia Muharom, dan Ahmad Madkur. "Integrating Character Education Values In Language Teaching: Why and How." dipresentasikan pada The Fourth ELITE International Conference, 2016.

Furqon Hidayatullah, M. Pendidikan Karakter: Membangun Peradaban Bangsa. Surakata: Yuma Pustaka, 2010.

Hajar Dewantoro, Ki. Bagian 1 Pendidikan. Yogyakarta: Majelis Luhur Taman Siswa, 1994.

Hamid Abidin, dkk,. Membangun Kemandirian Perempuan Potensi dan Pola Derma untuk Memberdayakan Perempuan serta Strategi Penggalangannya. Depok: Piramedia, 2009.

Jalaludin. Psikologi Agama.Jakarta:Grafindo, 1997.

Joyce Young, dkk. Menggalang Dana untuk Organisasi Nirlaba. Jakarta: PT. Ina Publikatama, 2007.

Kalida, Muhsin. Fundraising Taman Bacaan Masyarakat (TBM). Yogyakarta: Cakruk, 2012.

Koesoeman, Doni. Pendidikan Karakter: Strategi Mendidikn Anak di Zaman Global. Jakarta: Grafindo, 2010.

Latief, Hilman. Melayani Umat: Filantropi Islam dan Ideologi Kesejahteraan Kaum Modernis. Jakarta: PT Gramedia Pustaka Utama, 2010.

Lickona, Thomas. Pendidikan Karakter panduan Mendidik Siswa Menjadi 
Pintar dan Baik. Bandung: Nusa Media, 2008.

Marimba, D. Pengantar Filsafat Pendidikan Islam. Bandung: Al-Ma'arif, 1989.

N, Sudirman. Ilmu Pendidikan. Bandung: Remaja Rosdakarya, 1987.

Norton, Michael. Menggalang Dana: Penuntun untuk Lembaga Swadaya Masyarakat dan Organisasi Sukarela di Negara-negara Selatan. Jakarta: Yayasan Obor Indonesia, 2002.

"Pendidikan Karakter: Pengertian Pendidikan Karakter." Diakses 20 Oktober2017.http://belajarpsikologi. $\mathrm{com} /$ pengertian-pendidikankarakter/.

Rozi, Fahrur. Model Pendidikan Karakter dan Moralitas Siswa di Sekolah Islam Modern; Studi pada SMP Pondok Pesantren Selamat Kendal. Semarang: IANIN Walisongo, 2012.

S. Bamualim, Chaider, dan Irfan Abu Bakar. Revitalisasi Filantropi Islam. Jakarta: PBB UIN Syarif Hidayatullah, 2005.

Syarbini, Amirullah. Buku Pintar Pendidikan Karakter: Panduan Lengkap Mendidik Karakter Anak di Sekolah, Madrasah, dan Rumah. Jakarta: Prima Pustaka, 2012.

Tim Bahasa Pustaka Agung Harapan. Kamus Cerdas Bahasa Indonesia Terbaru. Bandung: CV Pustaka Agung Harapan, 2003.

Zubaedi.Desain Pendidikan Karakter:Konsepsi dan Aplikasinya dalam Lembaga Pendidikan. Jakarta: Kencana, 2011. 
20| Blementirliry Vol. 4 Edisi Januari-Juni 2018

halaman ini bukan sengaja untuk dikosongkan 